\title{
Moral Agency in Charities and Business Corporations: Exploring the Constraints of Law and Regulation
}

\author{
Eleanor Burt ${ }^{1} \cdot$ Samuel Mansell ${ }^{1}$
}

Received: 13 February 2017 / Accepted: 23 November 2017 / Published online: 20 December 2017

(c) The Author(s) 2017. This article is an open access publication

\begin{abstract}
For centuries in the UK and elsewhere, charities have been widely regarded as admirable and virtuous organisations. Business corporations, by contrast, have been characterised in the popular imagination as entities that lack a capacity for moral judgement. Drawing on the philosophical literature on the moral agency of organisations, we examine how the law shapes the ability of charities and business corporations headquartered in England to exercise moral agency. Paradoxically, we find that charities are legally constrained in exercising moral agency in ways in which business corporations are not. Implications for charities and business corporations are then explored.
\end{abstract}

Keywords Charity law and regulation · Company law · Corporate moral agency

\section{Introduction}

If we look forward across the centuries, from their early roots in the religious orders which distributed alms to the needy, through to 'the golden age of philanthropy' which saw Victorian charities laying the foundations of what was later to become the modern welfare state (Grant 2014; Williams 1989), to the acts of generosity and self-sacrifice displayed by staff and volunteers in the contemporary charitable sector, it is not difficult to see how charities may be regarded, prima facie, as organisations of good moral standing. The House of Lords Select Committee on Charities describes them as the 'eyes, ears and conscience of society' (2017, p. 3). By contrast, for-profit business corporations in general have been characterised as 'soulless' or even 'psychopathic' organisations (Bakan 2004, p. 28). Friedman and Miles (2006, p. 20), for example, write that the potential for corporations 'to do mischief to real people, combined with their lack of inherent moral sense, lack of a soul or 'feelings' for the consequences of their actions on others, such

Samuel Mansell

sfm5@st-andrews.ac.uk

Eleanor Burt

eb19@st-andrews.ac.uk

1 School of Management, University of St. Andrews, The Gateway, North Haugh, St. Andrews, Fife KY16 9RJ, UK as shame, remorse or gratitude' has led to various solutions aimed at curbing their power.

Notwithstanding this popular antithesis between charities and business corporations, we assess whether the former have more capacity for moral agency, in the context of English law, than the latter. By 'moral agency', we mean a capacity to act (from agere, to do or to act) on the basis of moral judgements. ${ }^{1}$ Exploring the philosophical and legal literature on this topic, we examine how English law restricts (or enables) the ability of charities and business corporations to exercise moral agency. In particular, we look at how charity law ${ }^{2}$ constrains the capacity of trustees to exercise

\footnotetext{
${ }^{1}$ Our understanding is that a 'moral agent' can act on a belief about whether an action is 'good' or 'bad', not merely as the most efficient means to an end, but in the light of considerations that are sensitive to conscience. The archetypical 'moral agent' is the individual human being; we later consider the sense in which an organisation itself can be a moral agent.

2 Our focus in this paper is charity law, as it is here that the constraints upon the moral agency of charities are first framed and originate. Clearly, however, the wider 'regulatory' context is also contributory, and, depending on how this is defined, this can be taken to include everything from the law more generally, to 'guidance' issued by regulatory bodies such as the Charity Commission for England and Wales or the Information Commissioner, to sector 'norms', and donor behaviours. While it is beyond the scope of the paper to have taken a 'broad gauge' approach, such as a wider interpretation of the 'regulatory context' would entail, we do acknowledge this in the course of the article in relation to the role of the Charity Commission for England and Wales : arguably the foremost 'prime mover' (or 'framer') next to the legal system itself.
} 
their consciences when acting on behalf of the charities they represent. We find that charity trustees are constrained in the exercise of conscience in ways that shareholders of a business corporation are not. Counter-intuitively, given the popular characterisations we have highlighted, our argument is that business corporations have greater capacity for moral agency than charities.

In England, charities are a legally recognised form of organisation, subject to particular legislative and regulatory requirements (Morris 2016; Harding 2014; Harding et al. 2014; McGregor-Lowndes and O'Halloran 2010). Problematically for English charities, for it is thought to be associated with lowering public trust in these organisations (Radojev 2016a, b; Smith 2015; Charity Communications 2014), there is a growing disconnection between the concept of charity as applied in law and the public perception of what it is to be a charitable organisation (Synge 2015; dal Pont 2014; Harding 2014; Parachin 2014). Thus, while notions that charities are essentially virtuous and altruistic shape public expectations of how these organisations ought to behave, being granted charitable status in law is not dependent upon, and does not require, the display of virtue by organisations seeking this status (dal Pont 2014; O'Halloran 2011). Instead, protecting the 'objects' which these organisations hold in trust is at the centre of charity law (Dekker and Harding 2014; Garton 2014).

In the philosophical literature on corporate moral agency (e.g. French 1979; List and Pettit 2011), it has been argued that any organisation must act according to a specific purpose if moral action can be meaningfully attributed to it. Charities are not unusual in this respect. However, we find that English law places specific restrictions on the 'objects' of charities, curtailing their scope for moral agency within the law. By comparison, it allows the shareholders and directors of business corporations more autonomy by giving them almost unlimited discretion in the purposes they pursue. Part of the explanation is to be found in how the law constitutes business corporations and charities: the former as a body governed in line with its members' interests, and the latter as a trusteeship accountable immediately to the Charity Commission for England and Wales (CCEW) and ultimately to donors, beneficiaries and the general public. This difference accounts in part, we argue, for the relative autonomy enjoyed by shareholders with respect to a corporation's constitution and purpose, but which is lacking from the decision-making powers of charity trustees.

We have selected the English charitable context as our 'case study' for a number of reasons. First, the issue that we examine here is highly relevant for English charities at the present time and is likely to remain so for the foreseeable future; yet, so far as we are aware, it has not been articulated and framed in the way presented in this article. Second, how 'charity' is conceptualised and the nature of accompanying legislative and regulatory requirements differ within different settings. Therefore, while modern-day England and Wales have adopted shared legislation and a shared regulatory body in the Charity Commission for England and Wales, Northern Ireland and Scotland each have their own charities Acts and regulatory bodies in the form of the Charity Commission for Northern Ireland and the Office of the Scottish Charity Regulator. This is the case, too, in the wider Commonwealth nations, the USA, and indeed, wherever the concept is embraced (Harding 2014; Harding et al. 2014; McGregor-Lowndes and O'Halloran 2010), whether particular countries have laws specifically pertaining to charities or not and whether they adopt the terminology of 'charity' or not (Piper 2012; 6 and Randon 1991). However, countries that have developed laws and regulations pertaining to charities have tended to draw upon English law, as they have shaped and evolved law and regulation to suit their own specific needs and contexts (Harding et al. 2014; Piper 2012; McGregor-Lowndes and O'Halloran 2010; 6 and Randon 1991). So, within these wider settings, there is a tradition of learning and drawing insights and broad principles from the English experience, together with a tendency to adjust and adapt practices to suit particular contexts.

Third, instances of charities acting in morally questionable ways are not confined to the English sector, with highprofile examples in evidence in countries ranging from Germany, to the USA, to Singapore, among others (Hopt 2010). For all of these reasons, we hope that our focus on the English context will provide a starting point for wider reflection and debate on the issue that we raise and examine in this article, not only within England and the wider UK, but wherever systems of charity law and regulation are in place or may emerge.

The article begins by setting out examples of charities behaving in ways at odds with public expectations. We then investigate the role of charity law in restricting the exercise of 'moral agency' on the part of charities, demonstrating that the directors and managers of business corporations may act for a wider range of reasons, including moral reasons, than their counterparts in charities. In conclusion, we consider the implications of our analysis for the moral responsibilities of institutional shareholders in shaping corporate activity. 
Furthermore, we argue that a misalignment of public policy and popular sentiment has resulted in diminishing levels of public trust in charities, and that policy-makers should revisit this predicament.

\section{Charities Behaving Badly}

In recent years, we have witnessed a raft of decisions and behaviours that at best seem not to sit well with organisations of good moral standing and at worst are perceived by the media, members of the public and others, as unscrupulous acts. There has been growing disquiet about issues ranging from executive pay and packages (Weakley 2015a; Mason 2013; Public Administration Select Committee 2013), to failure to pay the minimum and the living wage (Weakley 2015b), and the use of zero-hours contracts (Bloomfield 2013). There has been alarm, too, concerning the use of seemingly generous exit packages and 'gagging' clauses; the commodification and selling of personal data (BBC 2015; Radojev 2015); and the use of 'bullying' approaches and 'emotional blackmail' in fundraising (Anonymous 2015; Ribeiro 2013), to give further examples. In 2013, it was reported that a high-profile charity had severed links with bodies set up to oversee employee pay levels and would be implementing its own pay scale. The same charity also dismissed its employees, subsequently re-employing them on new contracts with altered employment conditions. The new conditions allowed casual staff to be placed on zero-hours contracts, reduced redundancy entitlements for eligible staff and removed overtime payments (Mason 2013). In 2014, it was alleged in the national press that another well-known and well-established charity had not only made significant payments to departing staff, but had also required them to sign 'gagging clauses' (Sharman 2014a).

More recently, a charity professional stated publicly that the truth is regularly manipulated by charities so that people will feel compelled to donate, thereby allowing targets set by the management team and trustees to be met (Anonymous 2015). More recently still, the Office of the Information Commissioner has investigated claims that the personal details of an 87-year-old, suffering from dementia, were sold or passed on by charities as many as 200 times. This resulted in more than 700 requests for donations and the loss of $£ 35,000$ when his details eventually reached the hands of fraudsters (BBC 2015).

The purpose here is not to evaluate whether these and other decisions taken by charities are by any or all standards either morally good or bad. It is simply to indicate that the very practical decisions that charities make every day about everything from severance payments, to how much to pay their cleaning staff, to what information to provide to potential donors, to which clients to take on and which to turn away, to the issues on which they will campaign ${ }^{3}$ are, in essence, matters that ought to require the exercise of moral agency (White 2010; Polman 2010; Slim 2014; Ainsworth 2017).

\section{Charity Law and the Exercise of Moral Agency}

Under English charity law, trustees have collective responsibility for the charities over which they have oversight. Thus, how a charity exercises moral agency ought, ultimately, to be their collective responsibility. In discharging this responsibility, however, charity law restricts the trustees in a number of ways (Morris 2016; Harries 2015; Dekker and Harding 2014; Hodgson 2012). Most crucially, in light of the public perception of what it is to be charitable, they are denied the liberty to act freely in line with their consciences. While trustees are each free to express their positions and discuss matters of moral concern, it is the fulfilment of the charitable 'object(s)' or purpose(s) that is sacrosanct and prime, and charities must not act in ways that may impact negatively on their achievement (Charity Commission for England and Wales 2015a; Harding 2014; Bates Wells and Braithwaite 2008).

So, while the trustees may know that by making employees redundant they will be unable to pay their mortgages, the impact on the employees and their families cannot be permitted to influence the trustees' decision. They may consider whether the charitable object can continue to be delivered in the absence of the staff redundancies and the budgetary savings that will follow from this course of action, but they cannot base their decision on the consequences that redundancies will have on the employees or their families. This is so, even though charities must deliver 'public benefit' as a key qualifying criterion for the awarding of charitable status. Thus, while it might be argued that there is public benefit in not making staff redundant, here, public benefit has the particular and narrower definition as laid out in the Charities Act 2011 (CA 2011). Under the Act, concerns with public benefit are directly related, and restricted, to the charitable

\footnotetext{
${ }^{3}$ Campaigning to change public and corporate policy as well as public attitudes is a key part of the work that some charities do and clearly matters of ethics and conscience are synonymous with this. Here, too, charity law imposes constraints on the actions of charities. We do not look at this aspect of charity law in this article as this area is currently being reviewed by the Government and is an evolving field at this time. Current indications are that it may become more restrictive. It is intended that this will be the subject of a future paper.
} 
objects ${ }^{4}$ and their benefit to the public or a section of the public deemed to be 'sufficiently numerous'. ${ }^{5}$ If in delivering the objects, there is some justifiable 'private benefit' to employees, through receiving a salary, that is fine, but it is the implications for the public benefit which must guide the decisions of trustees.

In the same way, the payment of competitive salaries and accompanying 'packages' to a number of senior staff may permit the charity substantially to improve its performance and therefore deliver its object more effectively. Even so, a decision of this nature may give concern to the trustees, not least because those whom they help are on the poverty line and few of their donors will enjoy similarly generous salaries and packages. The trustees are bound to consider the consequences of these remunerations on the charity's reputation and brand. They may decide that the risk to the charity's reputation and brand are too significant, and that donated income may markedly decline if existing and potential donors learn of the remunerations paid to staff. As this would adversely impact on the charity's ability to deliver its object, based on this evaluation the trustees may decide to revise the policy on remuneration of senior staff. What they may not do, however, is revise the policy because they regard the levels of remuneration as unconscionable when looked at in the context of those dependent on their services or the circumstances of their donors. Thus, while the requirement to consider the consequences to reputation and brand allow wider latitude to the trustees' reflections, they do so only in respect of the implications for the charitable object.

In their role as actors in the democratic polity charities are seen to represent and provide a 'voice' to those who would otherwise be marginalised and without influence (Purkis 2016; Harries 2015). Here, too, though, they must operate within the constraints of law. While various laws, standards and codes of conduct limit how charities undertake the range of activities that comprise this area of work,

\footnotetext{
${ }^{4}$ Commenting on the meaning of 'public benefit', Philip H. Pettit writes that the benefits 'must be related to the aims of the institution... The benefit from accidental and unplanned activities, or from incidental activities not related to a purpose of an institution, do not count towards the assessment of benefits' (2012, p. 285).

5 The difficulties encountered by the judiciary in deciding whether a charity's intended beneficiaries are a 'section of the public' are summarised by Pettit (2012, pp. 286-288). One problem concerns whether a section of the public must necessarily be identified by an 'impersonal' quality shared by its members, or whether it could be constituted by particular individuals. For example, a company's employees would not normally count as a section of the public, but if all the members of one profession (therefore sharing an impersonal' characteristic) were to be employed by one employer, the question would not be so easy to answer (ibid.). Trusts established for the relief of poverty are the exception to the rule: they may have charitable status even though the intended beneficiaries do not form a section of the public (ibid., p. 292).
}

charity law determines that charities restrict their advocacy to issues in support of their object (Charity Commission for England and Wales 2008). Their right to advocate within the democratic polity is not a blanket right to campaign on issues of moral concern per se (Morris 2016; and see, for example, cases Webb v. O’Doherty 1991; Baldry v. Feintuck 1972; National Anti-Vivisection Society, 1948).

English charity law goes further than this, though. It also prohibits charities from existing purely with the aim of securing or opposing a change in the law or for other 'political purposes' within England and in other countries in which the charities operate. Thus, and to draw from an example given by the Charity Commission for England and Wales (2008), if government policy is to allow the building of new runways at airports, an organisation established solely with the aim of bringing about a change in policy cannot be granted charitable status. Charities engaging in campaigning activities may do so only in support of, and ancillary to, their objects. Thus, to take a second example from the Charity Commission for England and Wales's (2008) guidance on campaigning and political activity, if a charity that provided counselling and refuge to victims of torture decided that this community and its own moral position would be better served by withdrawing these services and campaigning to expose the regime responsible, it could not do so and retain its charitable status. Nor are charities permitted to engage in activities that might be regarded as demonstrating support for one political party or another, however their policies sit with the consciences of the trustees. They may evaluate and set out the implications of a change of policy for their service users, but they must do so in a way that cannot be regarded as partisan.

Nor is it the case that altering the charitable objects would necessarily give trustees more latitude for moral discretion. There are limited grounds on which trustees (and others) can have the objects varied to accommodate their moral concerns about a trust's original purpose. For example, trust property can be applied cy-prés ('as near as possible') by a court to ensure 'purposes which are suitable and effective in the light of current social and economic circumstances' (CA 2011, s 67(3)). In the case of Canada Trust Co. v Ontario Human Rights Commission [1990] 69 DLR (4th) 321, a trust limiting the provision of scholarships to white Protestants was found to violate public policy on discrimination, and the condition imposing the restriction was therefore declared void. However, in such a case the trustees are still bound to implement what a court affirms to be the legitimate objects of the trust (e.g. those consistent with "current social circumstances'). They are not permitted to exercise moral judgement in pursuit of any objective beyond these terms.

Similarly, trustees who wish to offer a wider range of services than their objects permit must apply to have the objects changed, rather than act outside their scope. For example, 
the recent decision by Parliament permitting the Peoples Dispensary for Sick Animals (PDSA) to amend its objects, thereby enabling it to charge for services based upon a person's ability to pay for these (Sharman 2014b; Charity Commission for England and Wales 2014; Cabinet Office 2015) does not remove the constraints of charity law. It simply means that the options and consequences which exist now, within the PDSA, are different to those that went before.

\section{Charities and Corporate Moral Agency}

Is the moral agency of a charitable organisation therefore constrained to the extent that it must act according to its objects? ${ }^{6}$ In other words, does the requirement to prioritise the charity's purpose necessarily curtail the trustees' scope for moral decision-making? To address this concern, we turn to the literature on the moral agency of organisations. Although philosophers writing on this topic use the term 'corporate' moral agency and typically assume a context of commercial organisations (e.g. French 1979; Goodpaster and Matthews 1982; Moore 1999; Velasquez 2003, p. 533; Arnold 2006), their arguments do not apply only to legal corporations or to the for-profit sector. Rönnegard and Velasquez (2017, pp. 123-124) are explicit that it is the moral agency of organisations, or organised groups in general, that is in question. ${ }^{7}$ Drawing on this literature, we first explore the intuition that a statement of purpose curtails an organisation's agency. At this stage, we work merely with the idea that an organisation has 'agency', which is to say that actions may be attributed to it that are not the actions of its individual members. We then consider the more problematic (and much criticised) notion that an organisation is a moral agent, and advance a qualified endorsement of this position, before returning to the effects of charity and company law.

A point of agreement in the literature is that if an organisation has agency, it necessarily has purposes of its own that may differ from the separate goals of its members. A statement of purpose, or objects clause, would therefore not constrain organisational agency, but would be entailed by it. Without this assumption, one could not distinguish actions that belong to the whole organisation and for which members may share responsibility, from those taken by only one

\footnotetext{
${ }^{6}$ David Ciepley articulates a similar intuition in the context of a corporation's charter: all corporations declare a purpose 'in the founding charter that constrains the agency of the operating group' and 'the fact that corporations have an authorised purpose does not mean they have agency... the one constrains the other' (2015, pp. 28-29).

7 Pettit (2007, p. 172) lists churches, universities, partnerships, voluntary associations and even town meetings as examples of "corporate agents'.
}

member or a few that do not represent the whole group. On this point, French $(1979$, p. 213) argues: 'a corporate decision is recognised... by the policy it instantiates. Hence every corporation creates an image (not to be confused with its public image) or a general policy... that must inform its decisions for them to be properly described as being those of the corporation'. A corporate act, in other words, is one that is consistent with 'established corporate policy' (ibid.). Likewise, following (French 1979), Arnold (2006, p. 289) writes that 'to know how to act employees must have knowledge of how they are expected to act... Employees should have the appropriate intention, and if they do not they fail to properly represent the corporation' (emphasis in original). Furthermore, Manning (1984, p. 80) contends that 'it is by appeal to the goals of the organisation that we are able to ascribe an action to the organisation. If a captain runs a ship aground his action is not ascribed to the Navy, but if he takes his ship on routine maneuvers this action is ascribed to the Navy'.

If it is meaningful to attribute to an organisation the capacity to act (whether morally or not), then the organisation is logically required to have a specific purpose. Moreover, if 'organisational' actions are derived ultimately from the judgements or preferences of individual members (e.g. employees and shareholders), it is necessary to know by what criteria 'membership' is established: here again the presence of a defining purpose is necessary. To distinguish a 'conglomerate' (i.e. a group agent that can act) from a mere 'aggregate' of individuals, Pfeiffer (1990, p. 478) argues: 'such categorisation requires... a claim about the relevant purpose of those whose judgement is accepted as the basis for applying the membership criterion... The verdict in specific cases depends on which purposes one adopts'.

There is little agreement among these authors on which stakeholders should count as 'members' and therefore from whose actions the organisation's agency derives. In the case of the business corporation, French $(1979$, p. 212) includes everyone who is part of the 'personnel organisation for the exercise of the corporation's power' or, in other words, the corporation's 'internal decision structure'. On the other hand, Arnold (2006, p. 288) refers specifically to employees, whereas Moore (1999, p. 338) follows the legal position in the UK and USA in identifying the organisational 'state of mind' with the acts of directors and managers. Unusually, List and Pettit (2011, p. 40) also include shareholders. Having claimed that corporations 'exhibit the characteristics of agency in full dress', they assert: 'shareholders, directors, managers, and workers combine, often in subsidiary units, to ensure that they pursue the overall goals of their corporations'.

Notwithstanding these differences, the authors concur that an organisation's agency must be distinguishable from the attitudes of its individual members. This is a concern 
that we have raised in the case of charities, but it appears to hold across organisational forms. List and Pettit (2011, pp. 43-58) demonstrate that if group-level judgements are based on the corresponding attitudes of individual members, e.g. through majority voting on every proposition put before the group, then inconsistent group attitudes may followeven where the members' attitudes are consistent. As Pettit (2007, p. 183) argues, if members are to ensure the consistency of their collective decisions, they 'will have to create a group agent that comes apart in that manner from the way that they are individually disposed'. And furthermore, the 'group judgement may even be a judgement that every member rejects' (2007, p. 182).

The point is that group members can simulate the behaviour of an individual agent through a procedure that incorporates their attitudes into a 'group view' that is consistent from one decision to the next. As List and Pettit (2011, p. 75 ) put it: 'let a collection of individuals form and act on a single, robustly rational body of attitudes... and it will be an agent'. Furthermore, it will be autonomous 'to the extent that the features that make it an agent... are not readily reducible to features of the individual members: again, crucially, their attitudes' (pp. 76-77). Rönnegard and Velasquez (2017, p. 136), while criticising Pettit's argument for holding groups morally responsible, nonetheless concede that the organisation's 'procedural choice is inconsistent with member attitudes'. ${ }^{8}$

French (1979, p. 214) had arrived at a similar conclusion: 'the melding of disparate interests and purposes gives rise to a long range point of view that is distinct from the intents and purposes of the collection of incorporators viewed individually'. More recently, Soares (2003, p. 145) argued that corporations 'have interests in pursuing their established corporate goals despite the temporary, conflicting selfinterests of managers and directors'.

Earlier we outlined the predicament facing charity trustees concerning the influence of their individual consciences on the pursuit of the charitable object. However, we find that a formal purpose which enables organisational decisions that 'come apart' from members' attitudes is arguably a necessary condition for ascribing any action to an organisation. In this respect, there may be nothing distinctive about charities. Yet before developing a comparison with the business corporation to see if this finding holds, we must expand our conception of organisational agency. So far, we have affirmed

\footnotetext{
${ }^{8}$ Furthermore, Velasquez (2003, p. 544), though arguing persuasively that organisations lack the capacity for moral agency, allows that: 'Intentional properties such as purposes and beliefs, can be attributed to groups on the basis of a pattern which the activities of its members exhibit... And because the pattern is the result of the activities of many of the group's members, the intentional property... cannot be attributed to any single member.'
}

only that it is meaningful to speak of an organisation acting. But this is to say nothing of the moral quality of an organisation's actions, or of the moral capacities that an agent fit to be held responsible must possess. This is, after all, what is at stake in asking how the law constrains a charity's ability to act upon moral judgements. Indeed, there are compelling reasons to think that an organisation is not a moral agent in its own right.

The most persuasive reason, in our view, is that an organisation lacks the requisite internal capacities (e.g. for guilt, shame and empathy) that it would require to be an agent bearing moral (and not merely legal) rights and responsibilities. Velasquez (2003) argues that moral responsibility requires intention (p. 543), and organisational procedures for reaching collective decisions [of the kind defended by French (1979), and List and Pettit (2011)] cannot 'transform a metaphorical intention into a real one' because 'procedures and policies... cannot create group mental states nor group minds in any literal sense' (p. 546). Real intentionality requires a 'unified consciousness', which means that all the agent's intentions and beliefs are held in a 'single field of awareness' (p. 550). An organisation does not itself possess such a capacity. For the same reason, we can argue that an organisation does not literally have a conscience, because this would entail an internal sense, or consciousness, of right and wrong.

Moreover, Rönnegard and Velasquez (2017, p. 134) hold that a morally responsible agent has 'personal autonomy': an 'ability to hold a vantage point that is distinct from the agent's desires and allows the agent to choose which desire to act upon'. They ask whether the aggregation of member judgements to form a group view (as expounded by List and Pettit 2011) can generate personal autonomy in this 'morally relevant sense' (p. 136). They conclude that it cannot, because 'there is no sense in which a procedure is aware of its choice' (ibid.). Furthermore, Sepinwall (2017) explores the place of emotion in holding an agent to be an appropriate target for blame. The conclusion is again that organisations are deficient in this respect: 'it makes sense to blame only those who can experience guilt, affect is required to experience guilt, corporations have no capacity for affect, and so it makes no sense to blame corporations' (p. 144).

A further difficulty in treating organisations as moral agents is to determine a fair basis for apportioning responsibility among the members for what the organisation does in their name. 'Member responsibility', according to List and Pettit (2011, p. 164), 'is the responsibility that individuals have as the members of a group agent that does good or bad. It is derivative from the group agent's responsibility... although, importantly, their levels of member responsibility may vary with their roles in the group'. They add that even where some members are powerless to stop a group acting as it does, they may share in the group's responsibility 
'to the extent that they... explicitly or implicitly endorse the group's actions' (ibid.). Hasnas (2012) considers the implications of such an argument for the criminal punishment of organisations and raises a legitimate objection. $\mathrm{He}$ clarifies that moral responsibility is a prerequisite for blame, and blame merits punishment: 'if corporations are morally responsible agents, then they are properly eligible for criminal punishment...' (p. 190). He then argues that imposing such punishment on an organisation amounts to 'vicarious collective punishment', which is inherently unjust. He writes that 'there is no definite object to absorb the punishment': the costs pass through to various stakeholders (consumers, employees, shareholders, etc.), all of whom may be innocent of personal wrongdoing (p. 191). He demonstrates the incongruity of attributing moral responsibility to the organisation as a whole, precisely because of its imprecise extension to the members' individual responsibilities. ${ }^{9}$

To conclude this section, we agree with List and Pettit (2011) that a group's members can simulate an individual, rational agent by coordinating their judgements into 'a single system of attitudes held by the group as a whole' (p. 59). In this manner, they create a 'group agent', which may or may not have legal personality. However, if one accepts that to be morally responsible requires a unified consciousness, which the members possess individually, but their organisation does not, then what they cannot simulate is an individual moral agent. Hence, they cannot create a moral group agent, with rights and responsibilities of its own.

Does it follow that the idea of organisational moral agency is altogether redundant? We do not believe that it does. We see no reason to assume that an organisation's agency (i.e. the decisions taken on behalf of all the members) is necessarily a-moral, still less 'psychopathic' (Bakan 2004 , p. 28). Implicit in the view that charities are moral organisations capable of acting as the "conscience of society' (as the House of Lords report puts it) is the assumption that their trustees can act on collective judgements that are sensitive to moral considerations. An organisation's collective decisions can be described as 'moral', not only to the extent that they happen to cohere with social norms, but also insofar as they are responsive to moral concerns. This is not to say that the charity itself is a responsible moral agent.

\footnotetext{
${ }^{9}$ Historically, similar arguments have been made by advocates of the so-called fiction theory of corporate personhood, which holds that the 'will' of a corporation is not 'natural' but 'artificial' (man-made). For example, in On the Citizen (1997), Thomas Hobbes writes that if a decision contrary to 'natural law' is made on behalf of the body politic, 'the offender is not the commonwealth itself... but the citizens who voted for the decision. For an offence issues from an expression of natural will, not from a political will, which is artificial; because if it were the latter, those who voted against the decision would also be offenders' (1997, p. 97).
}

However, as List and Pettit put it: 'since the members of any group are able to form judgements on normative propositions in their individual lives, there is no principled reason why they should not be able to propose such propositions for group consideration and resolution-that is, for inclusion in the group's agenda' (2011, p. 159). To the extent that the members have the opportunity to debate matters of conscience that bear on the pursuit of the organisation's purpose, and thus to enact collective decisions that encompass moral judgements, we can speak appropriately of an organisation as a 'moral' agent. ${ }^{10}$ It is in this qualified sense that we now consider how the law constrains the moral agency of charities and business corporations.

\section{Charities and Business Corporations}

List and Pettit find it implausible that an organisation might be designed without a capacity to form collective attitudes on moral questions. They ask why any group of individuals should 'be allowed to incorporate under an organisational structure that deprives the group of the ability to assess its options normatively...' (2011, p. 159). In the case of a business corporation, typically there is at least one set of organisational members-i.e. the shareholders (simply called 'the members' in UK company law $)^{11}$ — who have the power to enforce normative judgements about the corporation's constitution and purpose, through their possession of certain legal rights. Moreover, unlike charities, business corporations today are rarely restricted legally to the pursuit of a specific purpose and there is considerable flexibility in law allowing both existing and new business corporations to engage in purposes which take them beyond profit-making (Wilson 2016). Before 2006, a company registered in the UK could not deviate from the 'objects' stated in its memorandum of association (Dine and Koutsias 2007). However, the Companies Act 2006 (CA 2006) states: 'unless a company's articles specifically restrict the objects of the company, its objects are unrestricted' (s 31(1)). The implication is that directors are largely freed from the constraint of a statement of objects. Hannigan (2015, p. 95) notes that companies formed under the new act 'generally do not restrict their objects... and therefore most companies have unrestricted capacity and no issue of ultra vires can arise'.

\footnotetext{
$\overline{10}$ The language of organisational moral agency can also be used appropriately in a non-literal sense: i.e., when it stands for 'the interactions among an amorphous group of people that produce morally unacceptable results' (Hasnas 2012, p. 194). When used for 'purely expressive purposes', such language 'reduces communicative transaction costs' (Hasnas, ibid.).

${ }^{11}$ In the UK, while charity law is devolved, company law (in the form of the Companies Act, 2006) extends to the whole of the UK.
} 
The fact that UK law allows unfettered discretion on the matter of corporate purpose does not, of course, imply that directors can interpret the goal of the company, however, they choose. As fiduciaries they owe 'undivided loyalty' to the company, which means they must promote its success without profiting from their position or entering into engagements that risk a conflict of interests (Hannigan 2015 , p. 257). But how are the interests of the company to be construed? The law vests ultimate authority to determine the purpose of the company, and to hold directors accountable for its pursuit, in the shareholders as a body. ${ }^{12}$ Section 172 states that: 'a director of a company must act in the way he considers, in good faith, would be most likely to promote the success of the company for the benefit of its members as a whole...' (CA 2006, s 172(1)). The 'members' in a company with share capital are the shareholders (s 8(1b)). In Hannigan's interpretation of section 172, "success' is a matter for the members to determine; they define the objectives of the company and then it is for the directors to promote the success of the company in those terms' (2015, p. 215). Accordingly, shareholders collectively have the right, for example, to appoint (s 160) and remove directors (s 168(1)), to approve directors' long-term contracts (s 188) and to amend the company's constitution (s 21(1)). Shareholders may also authorise directors' actions (or omissions) that would otherwise breach the fiduciary duties (e.g. the 'no-conflict' rule) directors owe to the company, or to ratify such actions later (CA 2006, s 180(4); Hannigan 2015, pp. 259-260).

Furthermore, they can submit and vote on proposals that would commit directors to addressing social and environmental issues, e.g. by preparing a sustainability report or implementing International Labour Organisation (ILO) standards. Despite the lack of widespread support for such proposals (Buchanan, et al. 2010), shareholders can in theory limit the imperative to maximise profits with corporate policies that serve the ends of non-shareholding stakeholders (Mansell 2013).

One might think that institutional investors, who now own the majority of financial assets in global capital markets (Hawley et al. 2014, p. 1), are bound to maximise short-term financial gains for their beneficiaries. However, a growing body of work finds this not to be the case. For example, Sandberg et al. (2014, pp. 354-355) explore how beneficiaries understand their own 'best interests' in the context of fiduciary duty. For their respondents, personal wealth is

\footnotetext{
12 This is the case notwithstanding the infrequency with which individual shareholders exercise their legal powers. Ireland (1999) charts the historical process through which shareholders, through the nineteenth century, relinquished their role as active owners of company property.
}

overall the 'least important factor' and few favour a 'strictly financial' conception of the fiduciary duties owed to them. Moreover, 95 per cent of their respondents 'answered that pension funds should consider SEE [social, ethical and environmental] issues in investment decisions' (ibid., p. 355). Shareholders indeed hold a privileged position in UK law in which they authorise directors to act in the company's interests. Or, as List and Pettit (2011, pp. 35-36) put it, they 'authorise' other members of the group agent (i.e. workers, managers and directors) to act on behalf of the whole group. Legally, the use shareholders make of this authority may be informed by their moral judgements and need not be limited to the pursuit of short-term financial gain.

By contrast, in English law none of these characteristics of a business corporation hold for a charitable organisation. There are no 'authorising' members, akin to shareholders, who define what counts as 'success' for the charity and authorise trustees to act on their behalf. To a certain extent, the Charity Commission takes an equivalent role. ${ }^{13}$ It can, for example, grant relief 'to a charity trustee... who appears to be personally liable for breach of trust or duty in relation to the trust where it considers that he has acted honestly and reasonably...' (Pettit 2012, pp. 312-313; CA 2011, s 191). In a business corporation, as we saw above, shareholders have the equivalent authority to ratify a breach of fiduciary duty by directors. However, power in the former case rests with an external agency that exists to regulate the entire sector in accordance with the 'public interest' — an interest which is not responsive to, and does not depend upon, the purposes that a given charity is founded to accomplish. By comparison, shareholders have greater liberty to define and interpret the purposes of the business corporations in which they invest, thus allowing more flexibility in the objectives that directors can pursue.

What is paramount for a charity, as we noted earlier, is that when trustees are to make any decision their options must be weighed strictly in relation to the charitable objects. Although the Charities Act gives trustees the power to make social investments (CA 2011, s 292B), part of its definition of a 'social investment' is that it is carried out with a view to 'directly furthering the charity's purposes' (CA 2011, s 292A). The trustees' moral judgements therefore cannot encroach upon the pursuit of the charity's object. And neither the organisation as a whole (e.g. the trustees, staff, volunteers and donors), nor any subset of members are free to amend the objects to permit value judgements that would otherwise conflict with them.

The Charities Act 2011 allows charities access to a number of corporate forms (including charitable companies,

\footnotetext{
13 The authors would like to thank an anonymous reviewer for this suggestion.
} 
charitable incorporated organisations (CIOs) and incorporations of charity trustees). Crucially, what each has in common is that the organisation is established solely for a 'charitable purpose' that 'is for the public benefit' (CA 2011 , s 2(1)). If any charity wishes to alter its stated purpose, it is constrained by these criteria and must refer such a request to the Charity Commission for England and Wales. For example, a charitable company cannot alter its statement of objects (s 198), or approve a director's long-term service contract (s 201), without the Commission's prior written consent. Likewise, the members of a CIO cannot alter its constitution without the Commission's consent (s 226). Similar restrictions apply to incorporated charity trustees and unincorporated charities. By contrast, a business corporation would refer all such decisions to its members.

Might it be objected that nothing precludes a charitable organisation from making value judgements that do not conflict with its purpose? Can it not draw on the consciences of its members to evaluate a restricted set of normative propositions? Indeed it could. However, every such proposition would be judged only as a means to the achievement of the stated purpose. Pettit (2007, p. 185) writes that a group agent fit to be held responsible 'will be able to make judgements as to the relative value of the options that they face...' We see no reason why this cannot be true of charity trustees; however, value would be determined relative to the charity's object. Pettit (2007, p. 175) argues that a responsible agent 'faces a value-relevant choice involving the possibility of doing something good or bad or right or wrong'. It is not that charity trustees do not face value-relevant choices, but rather that the content of 'right or wrong' is circumscribed by a narrow (or, to follow Kant, a 'perfect') duty to pursue the charitable object.

This is not to suggest that an organisation with charitable status is incapable of actions that conflict with its objects, for in that case there would be no need for the oversight of the Charity Commission. Ultra vires acts may indeed be informed by the moral judgement of the trustees, and accordingly be described as an exercise of moral agency, notwithstanding their illegality. For example, in its Case Report: Campaigning and Political Issues Arising in the Run-up to the 2015 General Election (2015b), the Charity Commission for England and Wales sets out a number of instances in which charities had to be reminded of the law prohibiting campaigning for a political party. These included the publishing of a letter on its public website by the National Council of Hindu Temples (UK) encouraging support for a particular political party in the General Election; the promotion by The Badger Trust of a march entitled 'Stop Cameron's Cull'; and a blog by the Chief Executive Officer of the League Against Cruel Sports entitled 'Making Our Votes Count for Wildlife and Animals'. The point is rather that, in restricting the objects a charity can pursue, the law limits the range of decisions trustees might refer to their consciences, and vests the interpretation of this limit in an external body. By contrast, commercial organisations (e.g. business corporations) are relatively unconstrained.

\section{Charities and Bodies Corporate}

Part of the explanation for this contrast is that a commercial organisation can refer to its membership a judgement about its fundamental purpose, whereas a charity cannot. While this difference holds between charities and all commercial organisations (e.g. partnerships and sole traders), it is illustrated here in the context of the corporate form. We therefore look at how shareholders are understood collectively in company law, in contrast to the donors and beneficiaries of a charity. According to the Companies Act 2006, an 'effect of registration' is that: 'the subscribers to the memorandum, together with such other persons as may from time to time become members of the company, are a body corporate by the name stated in the certificate of incorporation' (s 16(2)). As the 'body corporate' simply is the corporation as a person in law, legal capacity is effectively granted to the shareholders as a body. ${ }^{14}$ It follows that directors are legally accountable to shareholders for their pursuit of the corporation's purposes. Charity trustees, on the other hand, are accountable to the charity's beneficiaries, members (if it has them) and to those who fund them, but also to the Charity Commission-to whom they must refer all questions bearing on the charity's purpose. Furthermore, the Commission may intervene to direct the trustees 'to take any action that the Commission considers to be expedient in the interests of the charity' and 'may require action to be taken whether or not it would otherwise be within the powers exercisable by the person or persons concerned' (CA 2011, s 84; Pettit 2012, p. 310). This restriction on the trustees' autonomy means that, unlike a business corporation, a charity is not an independent 'body corporate' able to exercise its moral agency in pursuit of 'any lawful purpose'.

We noted earlier that the Charity Commission may be considered to act in an equivalent capacity to shareholders. The Commission has a certain degree of independence insofar as it is 'not subject to the direction or control of any Minister of the Crown or of another government department' (CA 2011, s 13(4)). However, its chairman and other members are 'appointed by the Minister for the Cabinet Office' and it must report to Parliament annually on the extent to which its objectives have been met (among other matters) (Pettit 2012, pp. 307-308).

\footnotetext{
${ }^{14}$ Hannigan (2015, p. 101) supports the view that, in the context of the company's constitution, the phrase 'the company as a whole' means 'the shareholders as a body' (or 'the corporators as a whole').
} 
Among the Commission's statutory objectives is an 'accountability objective': 'to enhance the accountability of charities to donors, beneficiaries and the general public' (CA 2011, s 14(5)). But it is not assumed that donors, beneficiaries and the general public together form 'bodies corporate' to whom charity trustees are accountable in the manner in which directors are answerable to shareholders. Nor can it be said that donors, beneficiaries and the public form part of a 'group agent' that encompasses trustees, staff and volunteers or, in the case of business corporations, shareholders, directors and employees (List and Pettit 2011, p. 40). Indeed, it is rarely (if ever) the case that donors, beneficiaries and the public have a direct collective voice in the running of a charity. Instead, their interests are deemed to be represented by the charity's 'purpose' as restricted by the 'public benefit' condition; and the authority to interpret this condition rests exclusively with the Charity Commission for England and Wales.

The relevant contrast is not therefore between charities and corporations per se. As we have observed, charities in English law can choose between several corporate forms. And as FW Maitland (2003) found, in his historical work on the English trust, the members of an unincorporated trust often had reason to act as corporations, and were viewed by the courts as if they were corporations, but operated behind a 'wall of trustees' who did not wish to invite the scrutiny of the state that would accompany formal incorporation. Maitland calls such entities 'unincorporated bodies' (2003, p. 104), i.e. bodies with members, but, ironically, without legal incorporation. An example is the London Stock Exchange which, from the early nineteenth century, had a large body of fee-paying members, a smaller body of proprietors who contributed a share capital of $£ 20,000$, and the board of trustees. In 1878, the members rejected a recommendation that they be incorporated by royal charter (Maitland 2003, pp. 108-109). However, Maitland writes that it would not 'be easy to find anything that a corporation could do and that is not being done' by this society (2003, p. 109).

The relevant distinction is between an organisation that has a 'body of members' able to interpret the corporate purpose and hold directors to account, and one which does not. Maitland contrasts a trust such as the London Stock Exchange (with its 'unincorporated body' of members) to a charitable trust. In the latter case, there is 'no pressing demand for a personal destinatory. We can, if we please, think of the charitable [purpose] as filling the place that is filled by a person in the ordinary private trust' (Maitland 2003, p. 104). In England today, as we have seen, the charitable purpose must conform to conditions established by the latest Charities Act. Even if the trustees were to succeed in altering their 'object', they could not have more autonomy than is permitted by the definitions of 'charitable purpose' and 'public benefit' in the interpretation of the Charity
Commission for England and Wales. To this extent, the shareholders of a business corporation are better able than charity trustees to implement their collective judgements on moral questions.

\section{Implications for Charities and Business Corporations}

In this section of the paper, we set out the implications for charities, for business corporations and for other bodies including public policy-makers. Turning first to charities, we have noted the growing disconnection between the concept of charity as applied in law and the public perception of what it is to be a charitable organisation on the one hand (Synge 2015; dal Pont 2014; Harding 2014; Parachin 2014), and associated lowering public trust in these organisations on the other hand (Radojev 2016a, b; Smith 2015; Charity Communications 2014). We have observed that while notions that charities are essentially of good moral standing shape public expectations of these organisations, being granted charitable status in law is not dependent upon a display of virtue (dal Pont 2014; O'Halloran 2011). Instead, protecting the 'objects' which these organisations hold in trust, while ensuring they are delivered in ways that fulfil the public benefit test, is what charity law requires (Dekker and Harding 2014; Garton 2014). We highlighted a number of issues, such as failure to pay the minimum wage (Weakley 2015b) and the use of zero-hours contracts (Bloomfield 2013), which do not sit well with the perception that charities are the conscience of society (House of Lords 2017). These seemingly unworthy behaviours have been roundly criticised by the media, members of the public, and others. Our analysis has demonstrated, however, that there may be circumstances in which trustees take decisions that seem unconscionable (e.g. to make staff redundant or to offer generous exit packages), because not to do so may jeopardise the fulfilment of the objects.

This is not the fault of the charity trustees, the law-makers, or those other bodies who regulate the charitable sector. It is an issue of public understanding, or lack thereof, which sits at the heart of the matter, and which we argue needs urgently to be addressed. For some time now, there has been evidence of a trajectory of diminishing public trust in charities (Radojev 2016b; Charities Aid Foundation 2015). This is important for two reasons. First, it is important because how people feel about charities impacts on the ability of these organisations to raise funds, as well as to attract employees, volunteers and other resources. It has been estimated that the damage to the charity 'brand' following the publication of several high-profile media reports during the summer of 2015 could cost the UK charitable sector more than $£ 6.5$ billion (Martin 2015). In turn, this impacts on the ability of charities to help those who are 
reliant on their support. Second, and perhaps more importantly, it matters because not only are charities powerful and influential actors that shape how we think and behave as a society (Ainsworth 2012; O'Halloran 2011; Hernes and Garston 2009), arguably they are also symbolic representations of society's highest ideals of goodness. If public trust in charities is to be strengthened and sustained in the short term, there needs to be better public understanding of the duties and constraints laid upon charities, and the complex challenges to which these give rise. In the longer term, it will be beneficial for public policy-makers, in consultation with other key stakeholders, to consider how improvements to the current situation may best be delivered.

In respect of business corporations, we can ask what positive responsibilities shareholders have as a consequence of the moral discretion we have argued that they possess. It is true that, in most cases, shareholders have only indirect control over the actions of directors (e.g. through voting on a director's removal). However, they can exercise their voting rights to collectively determine the interests of the corporations in which they invest, without reference to the 'public benefit' criterion (or an equivalent external interest) that restricts a charity's objectives. Our analysis suggests that an investigation into the moral requirements incumbent upon shareholders in the exercise of their voting rights should be central to an understanding of the corporation's proper purpose. Is it warranted to assume, for example, that shareholders authorise directors to pursue profit maximisation (or 'shareholder value'), as Friedman (1970) asserts? According to Stout (2012a, p. 1), it is a mistake to believe that shareholders generally have the same interest in maximising financial gain: 'there is no single shareholder value-different shareholders have different needs and interests depending on their investing time frame, degrees of diversification and interests in other assets, and perspectives on corporate ethics and social responsibility. Shareholder value ideology focuses on the interests of only a narrow subgroup of shareholders...' Her argument resonates with that of Sandberg et al. (2014), mentioned earlier, that beneficiaries of institutional funds do not have uniform interests in financial gain, and most tend to believe that social, ethical and environmental considerations are relevant to the investment decisions made on their behalf.

However, despite these findings, empirical evidence from UK-based companies indicates that support among shareholders for resolutions holding directors to specific ethical and environmental standards is weak (Mansell 2013, p. 592). For example, Buchanan et al. (2010, p. 7) found that just $2 \%$ of shareholder proposals focus on social and environmental concerns such as the implementation of International Labour Organization (ILO) standards or providing a sustainability report (ibid., p. 21). Furthermore, such proposals 'garner the lowest vote support and have the lowest passing rate compared to other types of proposals' (2010, p. 8). Similarly, Ertimur et al. (2011, p. 537) conclude that of shareholder proposals that target executive remuneration, those which align the objective of executive pay with social and environmental concerns have the poorest success rate (cited in Mansell 2013, p. 592).

The normative case can nonetheless be made that shareholders are responsible for monitoring how their corporations act and thus for ensuring that their organisations' agency is exercised morally. In other words, ethical considerations ought to be part of the joint deliberations through which shareholders hold directors to account. As List and Pettit (2011, p. 159) argue, if a group's members ordinarily act upon moral judgements in their personal lives, there is no reason why issues of moral concern that bear upon the group's interests cannot be subject to collective discussion and resolution.

As we observed above, it might be thought morally legitimate for shareholders to pursue financial gain to the exclusion of other goals, because equity markets are increasingly dominated by institutional investors who are, in turn, beholden to their beneficiaries for maximising the financial value of their investments. As Lydenberg (2014, p. 287) observes, under modern portfolio theory fiduciaries act 'rationally' when they prioritise short-term economic gains, and this 'rational' approach crowds out considerations of how fiduciaries serve 'the lives of their beneficiaries and world in which they live' (p. 290). However, concordant with the findings of Sandberg et al. (2014), he argues we should ask not what 'rational', short-term financial interest requires of fiduciaries, but instead what should be expected of a reasonable fiduciary. The latter would determine "what, in their best judgement, the objective state of their beneficiaries and the world in which they live is and whether their investment decisions on the whole are contributing positively to that state' (p. 294). When investors take more than financial value into account, they must ask questions 'about whether their investments have a net positive effect on the economy (including society and the environment) and the financial system as a whole' (p. 296).

\section{Conclusion}

Charities have tended to be regarded as worthy and admirable organisations. Business corporations, by contrast, have been characterised in the popular imagination as 'soulless' entities that lack a capacity for moral judgement. We examined how English and UK law shape the scope for moral agency in charities and business corporations and found, counter-intuitively, that the exercise of moral agency by charities is limited to a greater extent than it is for business corporations. This is because English law places specific 
restrictions on the 'objects' pursued by a charity's trustees, of which there is no equivalent in the general fiduciary duties owed by the directors of a business corporation. In turn, shareholders have greater latitude to shape the purposes of their organisations, even in the context of institutional investment, than charity trustees possess. For example, the law bestows exclusive powers upon shareholders to alter a corporation's constitution and to hold directors accountable for the firm's performance, whereas charity trusteesconfined to the pursuit of a specific purpose approved in law-have no such independence. We concluded that the explanation lies partly in how the law constitutes business corporations and charities: the former as an entity governed to promote the 'internal' interests of its own members, and the latter as a trusteeship designed to serve the 'external', public interest safeguarded (in this context) by the Charity Commission for England and Wales.

Two key implications for charities are to be drawn. First, the disconnection between the duties and constraints laid upon trustees by charity law and the public perception of how charities ought to behave has contributed to diminishing levels of trust in these organisations. This needs urgently to be addressed through public education. We hope that this paper begins that process. Second, despite the constraints we have identified there is value in charity trustees taking time, on a regular basis, to ask penetrating questions of their collective moral position and individual consciences. Charities which subject their strategic, operational and other business decisions, to scrutiny of this sort, will be better placed to retain and grow public trust than those which do not, for they will at least be able to demonstrate and explain why (seemingly) morally questionable decisions have been taken.

There are implications, too, for public policy-makers. Current and future governments, together with other key stakeholders, need to think about and discuss what they want, and what it is reasonable to expect, from charities by comparison with non-charitable organisations. We hope that by setting out how charities are constrained from exercising moral agency, through a juxtaposition with the case of the business corporation, we have provided a way forward for that reflection and debate; for, clearly, change is needed. Its delivery will not be straightforward, however, and setting out the form which it should take is beyond the scope of the present paper. Charities are complex organisations, operating in complex environments and facing complex challenges: public policy interventions will need to be sensitive to this and appropriately nuanced.

Finally, with regard to business corporations, our analysis provides an additional reason to question the collective purpose of shareholder investment and the extent to which share price, or another measure of financial gain, either is or should be the overriding goal. Our comparison with charities illuminates the fact that whereas the former are held to the standard of 'public benefit', business corporations have broader scope to pursue objectives that reflect the particular interests of their members. It can therefore be argued that despite shareholders' position at the centre of corporate governance having received sustained criticism in recent years (e.g. from Ireland 2010; Sacconi 2011; Deakin 2012; Stout 2012b; Veldman and Parker 2012), while the law concentrates authority in their hands, there is reason to ask to what end they should use it. This is especially the case in the context of 'shareholder activism' and calls for greater 'say on pay' (Marriage 2017; Marlow 2017).

How can moral considerations (for example, regarding social, ethical and environmental issues) be better integrated into the process through which shareholder powers are exercised? While an examination of this problem is beyond the scope of the present article, there are at least two promising fields of research in this area. One is, as we have seen, a renewed normative enquiry into the scope of the fiduciary duties owed by institutional investors to their beneficiaries. This research, which argues for an extended remit for institutional investors beyond that of financial gain, complements philosophical work on the positive duties owed by shareholders to other stakeholders (Mansell 2013; cf. Hsieh 2017). A second development in this field concerns the mechanisms through which shareholders commit to the values of the corporations in which they invest. Mayer (2013, pp. 8-9), for example, develops the concept of a 'trust firm', i.e. a firm that identifies a set of values to be protected by a board of trustees, and commits controlling shareholders to hold their shares for a fixed time period, thereby delineating 'for how long and over what activities the corporation can credibly commit...' (p. 8). In summary, an appreciation for the limits that different organisations (including charities and business corporations) face in determining and pursuing their own objectives helps to delimit the ethical questions that should be asked, both of how they use the resources entrusted to them, and to what end.

\section{Compliance with Ethical Standards}

Conflict of interest The authors have no potential conflicts of interest.

Human and Animals Rights No data were taken from human beings or other animals in this research.

Open Access This article is distributed under the terms of the Creative Commons Attribution 4.0 International License (http://creativecommons.org/licenses/by/4.0/), which permits unrestricted use, distribution, and reproduction in any medium, provided you give appropriate credit to the original author(s) and the source, provide a link to the Creative Commons license, and indicate if changes were made. 


\section{References}

Ainsworth, D. (2012). Charities should set an example on ethical investment. Third Sector, 17th October. Downloaded 3rd September 2015 .

Ainsworth, D. (2017). Mencap cuts staff numbers by over 200 and spends $£ 1 \mathrm{~m}$ on redundancies. Civil Society, http://www.civilsociety.com/. Downloaded January 8th.

Anonymous. (2015). We must hook donors in, but I feel downright sick at the picture charities paint. Blog-Confessions of a charity professional series, The Guardian, 15th February. http://theguardian. com/. Downloaded February 20th, 2015.

Arnold, D. (2006). Corporate moral agency. Midwest Studies in Philosophy, 30, 279-291.

Bakan, J. (2004). The corporation: the pathological pursuit of profit and power. London: Constable.

Baldry v. Feintuck. (1972). Case law, 552-1972.

Bates Wells and Braithwaite. (2008). Duties of charity trustees. London: Bates Wells and Braithwaite.

BBC. (2015). Charities could face fundraising ban for breaking rules. 24th September. http://bbc.co.uk/. Downloaded September 23rd, 2015.

Bloomfield, J. (2013). Why is the third sector using zero hours contracts? Blog (16th December) Scottish Council for Voluntary Organisations. http://scvo.org.uk. Downloaded December 17th, 2013.

Buchanan, B., Netter, J., \& Yang, T. (2010). Are shareholder proposals an important corporate governance device? Evidence from US and UK shareholder proposals. Available at SSRN: http://ssrn. com/abstract=1572016. Accessed April 5th, 2012

Cabinet Office. (2015). The Charities (People's Dispensary for Sick Animals) Order 2015. Statutory Instruments 2015. No. 198. Charities, England and Wales. London: Cabinet Office.

Charities Aid Foundation. (2015). Under the microscope. London: Charities Aid Foundation.

Charity Commission for England and Wales. (2008). Speaking out: Guidance on campaigning and political activity by charities. London: Charity Commission for England and Wales.

Charity Commission for England and Wales. (2014). People's dispensary for sick animals-208217. London: Charity Commission for England and Wales.

Charity Commission for England and Wales. (2015a). Case report: Campaigning and political issues arising in the run-up to the 2015 general election. London: Charity Commission for England and Wales.

Charity Commission for England and Wales. (2015b). The essential trustee: What you need to know, what you need to do. London: Charity Commission for England and Wales.

Charity Communications. (2014). Briefing document for the understanding charities group. London: Charity Communications.

Ciepley, D. (2015, working paper). Will and responsibility in member corporations, property corporations, and firms. Presented to the St Andrews Conference on Corporate Agency and Shared Responsibility, University of St Andrews, November 2nd-3rd, 2015. Text on file with author.

Dal Pont, G. E. (2014). Charity law: 'No magic in words'? In M. Harding, A. O'Connell, \& M. Stewart (Eds.), Not-for-profit law: Theoretical and comparative perspectives. Cambridge: Cambridge University Press.

Deakin, S. (2012). The corporation as commons: Rethinking property rights, governance and sustainability in the business enterprise. Queen's Law Journal, 37(2), 339-381.

Dekker, C., \& Harding, M. (2014). Three challenges in charity regulation: The case of England and Wales. In M. Harding, A. O'Connell, \& M. Stewart (Eds.), Not-for-Profit law: Theoretical and comparative perspectives. Cambridge: Cambridge University Press.

Dine, J., \& Koutsias, M. (2007). Company Law (6th ed.). Basingstoke: Palgrave Macmillan.

Ertimur, Y., Ferri, F., \& Muslu, V. (2011). Shareholder activism and CEO pay. The Review of Financial Studies, 24(2), 535-592.

French, P. (1979). The corporation as a moral person. American Philosophical Quarterly, 16(3), 207-215.

Friedman, M. (1970). The social responsibility of business is to increase its profits. New York Times Magazine 13th September. Available at: http://www.colorado.edu/studentgroups/libertarians/ issues/friedman-soc-resp-business.html. Accessed June 13th, 2017.

Friedman, A., \& Miles, S. (2006). Stakeholders: Theory and practice. Oxford: Oxford University Press.

Garton, J. (2014). The fault line of charity. In M. Harding, A. O'Connell, \& M. Stewart (Eds.), Not-for-profit law: Theoretical and comparative perspectives. Cambridge: Cambridge University Press.

Goodpaster, K.E., \& Matthews, J.B. (1982). Can a corporation have a conscience? Harvard Business Review, 60, 132-141.

Grant, P. (2014). Philanthropy and voluntary action in the first world war: Mobilizing charity. London: Routledge.

Hannigan, B. (2015). Company law (4th ed.). Oxford: Oxford University Press.

Harding, M. (2014). Charity law and the liberal state. Cambridge: Cambridge University Press.

Harding, M., O'Connell, A., \& Stewart, M. (Eds.). (2014). Not-forprofit law: Theoretical and comparative perspectives. Cambridge: Cambridge University Press.

Harries, R. Lord Harries of Pentregarth (Ch) Commission on Civil Society and Democratic Engagement. (2015). Non-party campaigning ahead of elections: Consultation and recommendations relating to part 2 of the Transparency in Lobbying, Non-party Campaigning and Trade Union Administration Bill. Report 4. London: Commission on Civil Society and Democratic Engagement.

Hasnas, J. (2012). Reflections on corporate moral responsibility and the problem solving technique of Alexander the Great. Journal of Business Ethics, 107(2), 183-195.

Hawley, J., Hoepner, A., Johnson, K., Sandberg, J., \& Waitzer, E. (2014). Introduction. In J. Hawley, A. Hoepner, K. Johnson, J. Sandberg, \& E. Waitzer (Eds.), Cambridge handbook of institutional investment and fiduciary duty (pp. 1-6). Cambridge: Cambridge University Press.

Hernes, T., \& Garston, C. (Eds.). (2009). Ethical dilemmas in management. Oxon: Routledge.

Hobbes, T. (1997). On the three kinds of commonwealth: Democracy, aristocracy and monarchy. In R. Tuck \& M. Silverthorne (Eds.), On the citizen. Cambridge: Cambridge University Press.

Hodgson, L. (2012). Trusted and independent-Giving charity back to charities: Review of the Charities Act 2006. London: The Stationery Office.

Hopt, K. J. (2010). The board of nonprofit organizations: Some corporate governance thoughts from Europe. In K. J. Hopt \& T. von Hippel (Eds.), Comparative corporate governance of non-profit organizations. Cambridge: Cambridge University Press.

House of Lords Select Committee. (2017). Stronger charities for a stronger society. Report of Session 2016-2017. HL 133. London: House of Lords Select Committee on Charities.

Hsieh, N. (2017). Corporate moral agency, positive duties, and purpose. In E. Orts \& N. Smith (Eds.), The moral responsibility of firms (pp. 188-205). Oxford: Oxford University Press.

Ireland, P. (1999). Company law and the myth of shareholder Ownership. Modern Law Review, 62(1), 32-57. 
Ireland, P. (2010). Limited liability, shareholder rights and the problem of corporate irresponsibility. Cambridge Journal of Economics, 34, 837-856.

List, C., \& Pettit, P. (2011). Group agency: The possibility, design, and status of corporate agents. Oxford: Oxford University Press.

Lydenberg, S. (2014). Reason, rationality and fiduciary duty. In J. Hawley, A. Hoepner, K. Johnson, J. Sandberg, \& E. Waitzer (Eds.), Cambridge handbook of institutional investment and fiduciary duty (pp. 287-299). Cambridge: Cambridge University Press.

Maitland, F. (2003). Trust and corporation. In D. Runciman \& M. Ryan (Eds.), State, trust and corporation. Cambridge: Cambridge University Press.

Manning, R. (1984). Corporate responsibility and corporate personhood. Journal of Business Ethics, 3(1), 77-84.

Mansell, S. (2013). Shareholder theory and Kant's 'duty of beneficence'. Journal of Business Ethics, 117(3), 583-599.

Marlow, B. (2017). Shareholders must be allowed the last say on pay. The Telegraph 11th February. Available at: http://www.telegraph. co.uk/business/2017/02/11/shareholders-must-allowed-last-saypay/. Accessed June 15th, 2017.

Marriage, M. (2017). Executive pay rebellions loom in 'shareholder spring'. Financial Times 14th February. Available at: https://www.ft.com/content/4d02fb44-ef93-11e6-930f061b01e23655?mhq5j=e1. Accessed June 15th, 2017.

Martin, G. (2015). Scandals could cost charities billions. Third Force News (11th September). Edinburgh: SCVO.

Mason, T. (2013). NCVO Chair warns attacks on charity sector threaten its existence. Civil Society, 11th November. http://www. civilsociety.com/. Downloaded November 12th, 2013.

Mayer, C. (2013). Firm commitment. Oxford: Oxford University Press.

McGregor-Lowndes, M., \& O'Halloran, K. (Eds.). (2010). Modernising charity law: Recent developments and future directions. Cheltenham: Edward Elgar.

Moore, G. (1999). Corporate moral agency: Review and implications. Journal of Business Ethics, 21(4), 329-343.

Morris, D. (2016). Legal limits on political campaigning by charities: Drawing the line. Voluntary Sector Review, 7(1), 109-115.

National Anti-Vivisection Society. (1948). Case law. Appeal Cases $31-1948$

O'Halloran, K. (2011). The politics of charity. London: Routledge.

Parachin, A. (2014). The role of fiscal considerations in the judicial interpretation of charity. In M. Harding, A. O'Connell, \& M. Stewart (Eds.), Not-for-profit law: Theoretical and comparative perspectives. Cambridge: Cambridge University Press.

6, P., \& Randon, A. (1991). Liberty, charity and politics: Non-profit law and freedom of speech. Aldershot: Dartmouth.

Pettit, P. (2007). Responsibility incorporated. Ethics, 117(2), 171-201.

Pettit, P. (2012). Equity and the law of trusts (12th ed.). Oxford: Oxford University Press.

Pfeiffer, R. (1990). The central distinction in the theory of corporate moral personhood. Journal of Business Ethics, 9(6), 473-480.

Piper, A.-M. (Ed.). (2012). Charity law: Jurisdictional comparisons. London: Thomson Reuters.

Polman, L. (2010). War games: The story of aid and war in modern times. London: Penguin.

Public Administration Select Committee. (17th December 2013). Charity chief executive pay. HC 831. London: House of Commons.

Purkis, A. (2016). The positive role of charities in public policy and awareness: Evidence to House of Lords select committee on charities. London: House of Lords.

Radojev, H. (2015). IoF Ban selling of donor data as part of latest code amendments. Civil Society, 21st September. https://www. civilsociety.co.uk. Downloaded August 11th, 2015.
Radojev, H. (2016a). Military charities accused of sensationalising post-combat stress to get more donations. Civil Society, 2nd September. https://www.civilsociety.co.uk. Downloaded November 12 th, 2016.

Radojev, H. (2016b). Two thirds of the public don't trust charities to use their data properly. Civil Society, 30th August. https://www. civilsociety.co.uk. Downloaded November 12th, 2016.

Ribeiro, C. (2013). Charity ads placed under scrutiny by advertising regulator. Civil Society, 4th November. https://www.civilsociety. co.uk. Downloaded August 11th, 2015.

Rönnegard, D., \& Velasquez, M. (2017). On (Not) attributing moral responsibility to organizations. In E. Orts \& N. Smith (Eds.), The moral responsibility of firms (pp. 123-142). Oxford: Oxford University Press.

Sacconi, L. (2011). A Rawlsian view of CSR and the game theory of its implementation (Part I): The multi-stakeholder model of corporate governance. In A. Sacconi, M. Blair, R. Freeman, \& A. Vercelli (Eds.), Corporate social responsibility and corporate governance. The contribution of economic theory and related disciplines (pp. 157-193). New York: Palgrave MacMillan.

Sandberg, J., Jansson, M., Biel, A., \& Gärling, T. (2014). Understanding the attitudes of beneficiaries: Should fiduciary duty include social, ethical and environmental concerns? In J. Hawley, A. Hoepner, K. Johnson, J. Sandberg, \& E. Waitzer (Eds.), Cambridge handbook of institutional investment and fiduciary duty (pp. 353-363). Cambridge: Cambridge University Press.

Sepinwall, A. (2017). Blame, emotion, and the corporation. In E. Orts \& N. Smith (Eds.), The moral responsibility of firms (pp. 143166). Oxford: Oxford University Press.

Sharman, A. (2014a). Blue cross alleged to have paid out $£ 180,000$ to gag departing staff. Civil Society, 24th February. https://www. civilsociety.co.uk/. Downloaded February 25th, 2014.

Sharman, A. (2014b). PDSA plans to change objects to offer paid for services. Civil Society, 19th December. https://www.civilsociety. co.uk/. Downloaded December 19th, 2014.

Slim, H. (2014). Humanitarian ethics: A guide to the morality of aid in war and disaster. London: Hurst.

Smith, S. (2015). Why do we need a third sector anyway? Third Force News, 19th August. http://thirdforcenews.co.uk/. Downloaded August 20th, 2015.

Soares, C. (2003). Corporate versus individual moral responsibility. Journal of Business Ethics, 46(2), 143-150.

Stout, L. (2012a). The problem of corporate purpose. Issues in Governance Studies, 48, 1-14.

Stout, L. (2012b). The shareholder value myth: How putting shareholders first harms investors, corporations, and the public. San Francisco, CA: Berrett-Koehler Publishers.

Synge, M. (2015). The 'new' public benefit requirement: Making sense of charity law?. Oxford: Hart.

Velasquez, M. (2003). Debunking corporate moral responsibility. Business Ethics Quarterly, 13(4), 531-562.

Veldman, J., \& Parker, M. (2012). Spectres Inc: The elusive basis of the corporation. Business and Society Review, 117(4), 413-441.

Weakley, K. (2015a). The story in The Times isn't nonsense, the sector needs to sit up and take notice. Civil Society, 12th December. http://civilsociety.co.uk/. Downloaded June 30th, 2016.

Weakley, K. (2015b). Horse charity second in minimum wage list of shame. Civil Society, 25th October. http://civilsociety.co.uk/. Downloaded October 29th, 2015.

Webb v. O'Doherty. (1991). Case law, 822-1991.

White, D. (2010). The nonprofit challenge: Integrating ethics into the purpose and promise of our nation's charities. New York: Palgrave Macmillan. 
Williams, I. (1989). The alms trade: Charities past, present, and future. London: Unwin Hyman.

Wilson, N. C. (2016). On a mission in the UK economy: Current state of play, vision and recommendations from the advisory panel to the Mission-led Business Review 2016. London: Office for Civil Society, Department of Culture, Media and Sport. 